\title{
Students' Perception of the Implementation of Democratic Classroom in Mathematics Learning
}

\author{
Rahmah Johar \\ Mathematics Education Department \\ Syiah Kuala University \\ Indonesia rahmahjohar@fkip.unsyiah.ac.id \\ Dian Patmawati \\ Mathematics Education Department \\ Syiah Kuala University \\ Indonesia \\ Said Munzir \\ Mathematics Department \\ Syiah Kuala University \\ Indonesia
}

\begin{abstract}
In most mathematics lesson in Indonesian schools, students often have lack of opportunities to express their opinion in solving problems. Furthermore, the lesson is less interactive which lead to students not being fond of mathematics. One of the solutions for this problem is by implementing the democratic classroom using Realistic Mathematics Education (RME). This is a qualitative study to analyze the students' perception of the implementation of democratic classroom conducted by their teachers using the RME approach. 23 of Year 7 students in Banda Aceh participated in the study. The research instruments were the questionnaire and interview. Descriptive analysis was carried out to identify the percentage of students who respond to the questions related to the democratic classroom. The results show that there are 12 characteristics of democratic classroom. 10 out of which are implemented by the teacher, while the other two including providing feedbacks on all students' presentation and allowing students the opportunity to express opinion or conclusion at the end of the lesson have not been implemented well. One of the factors that hinder the optimum implementation of the democratic classroom was the time constraint. This study indicates that a well-planned of lesson time for the activities conducted is necessary for teachers to successfully implement the characteristics of the democratic classroom.
\end{abstract}

Keywords-perception; democratic classroom; mathematics learning

\section{INTRODUCTION}

The majority of Indonesian teachers have a lack of practice in developing students' reasoning and problem solving ability [1]. Mathematics lessons are mostly begun by presenting abstract information such as definition, formula or standard algorithm [2, 3, 4]. These results in less interactive learning, students having lack of opportunities to express their opinions in solving problems, students being "forced" to accept less meaningful learning, students having lack of opportunities to solve contextual problems or issues, and therefore these lead to many students not being fond of mathematics.

The government has been consistently appealed teachers to teach mathematics in a way to make students like mathematics. The government has provided trainings and textbooks and therefore many teachers are aware of the importance of developing students' mathematics logical and creative thinking skills as well as mathematical problem solving skill. However, the majority of the teachers have lack of understanding of how to conduct a democratic classroom of mathematics learning in order to influence students to like mathematics and develop the skills.

Dewey said that it is necessary to develop democratic education in schools as it will not only prepare students for future life in the society but also provide students opportunities to have experience being part of the school society [5]. The democratic values are influenced by the values of democratic teachers [6]. Therefore, teachers play a pivotal role in developing democratic values in order to enable the class to be a significant place to develop the democracy habits [7, 8]. Furthermore, [9] explained that the aspects of democratic classroom are reflected by the freedom, equality and dialogue between students as well as between students and teachers.

One of the approaches for implementing the democratic classroom is Realistic Mathematics Education (RME). RME was developed in the Netherlands by Freudenthal in 1973. Freudenthal argued that mathematics is a human activity and therefore it should be connected to the reality. Gravemeijer explained that RME is one of the mathematics learning approaches oriented to mathematizing daily experiences and implementing them in daily life [10]. RME is known as Pendidikan Matematika Realistik Indonesia (PMRI) in 
Indonesia. Sembiring explained that with PMRI, mathematics is presented to students as a process of reinventing and therefore it demands for students' creativity and initiative [11]. Students are suggested to work in group to stimulate discussion and to grow respects of others opinion. Students are guided by the teachers to discover whether their answer is correct or wrong using their own way. Teachers are suggested not to decide by themselves whether the answer is correct or not. PMRI does not only reform the mathematics education in Indonesia but also promote the democratic culture.

There have been some studies related to students' mathematics competences such as connection, communication, reasoning, problem solving, representation and understanding. There is lack of studies focusing on analyzing students' perception of classroom situation related to the development of those competences despite the fact that students' perception is one of the significant physiological factors in learning processes. According to [12], perception is the sight of how someone sees something or in a wider definition perception is the view of how someone views or interprets something. As a complex psychological construct, perception is hard to formulate as a whole. Perception is the process by which organisms interpret and organize sensation to produce a meaningful experience of the world [13]. Students' perception of certain object attracting them in the learning process in schools provide different information and feedbacks for the same object because perception is influenced by several factors including personality, attitude or motivation. Basically, the process of forming the perception is happened in oneself. However, the perception is also influenced by the learning process experience and knowledge. This paper discusses students' perception of the implementation of democratic classroom conducted by teachers using the RME approach.

\section{METHODS}

This research employed a qualitative method. The data collection was conducted in one of Year 7 classes in one of Junior high school in Banda Aceh. The lesson was conducted twice in November 2016 for the topic of one variable linear equation using RME. The researchers together with the teacher designed the lesson plan and worksheet consisting of problem solving tasks using RME approach. The teacher involved was 35 years old and has been teaching in the school for 14 years. During the lesson, students were divided into five study groups to discuss the problems provided. The lesson was video-recorded which was placed in three groups of students.

The instrument used in this study were an open-ended questionnaire and interview. The questionnaire consisted of 12 questions containing democratic classroom values such as freedom, equality and dialogue developed by [8]. The questions included in the questionnaire are presented in Table 1 .
TABLE I. THE QUESTIONNAIRE OF STUDENTS' PERCEPTION OF DEMOCRATIC CLASSROOM 2003

\begin{tabular}{|c|c|c|}
\hline $\begin{array}{l}\text { Aspect } \\
\text { of } \\
D C\end{array}$ & No & The Question in the Questionnaire \\
\hline \multirow{8}{*}{ Freedom } & \multirow{8}{*}{$\begin{array}{c}1,2,3,4,5 \\
6,8,11\end{array}$} & $\begin{array}{l}\text { Are you given the opportunity to express your } \\
\text { opinion or questions during the lesson? }\end{array}$ \\
\hline & & $\begin{array}{l}\text { Are you given the freedom to use tools or other } \\
\text { reading resources during the lesson? }\end{array}$ \\
\hline & & $\begin{array}{l}\text { Does the teacher limit the time when you present } \\
\text { your group work? }\end{array}$ \\
\hline & & $\begin{array}{l}\text { Does the teacher refute you during the } \\
\text { presentation? }\end{array}$ \\
\hline & & $\begin{array}{l}\text { Does the teacher give you freedom to work on the } \\
\text { worksheet using your own way? }\end{array}$ \\
\hline & & $\begin{array}{l}\text { Are you given the opportunity to criticize your } \\
\text { score of the assessment? }\end{array}$ \\
\hline & & $\begin{array}{l}\text { Does the teacher suddenly interrupt you when you } \\
\text { express your opinion? }\end{array}$ \\
\hline & & $\begin{array}{l}\text { Are you given the opportunity to ask questions, } \\
\text { opinions or the conclusion of the learning at the } \\
\text { end of the lesson? }\end{array}$ \\
\hline \multirow{2}{*}{ Dialogue } & \multirow{2}{*}{7,9} & $\begin{array}{l}\text { Does the teacher provide you the opportunity to } \\
\text { discuss? }\end{array}$ \\
\hline & & $\begin{array}{l}\text { Does the teacher provide you the opportunity to } \\
\text { help the member of your group who struggle? }\end{array}$ \\
\hline \multirow{2}{*}{ Equality } & \multirow{2}{*}{10,12} & $\begin{array}{l}\text { Does the teacher comment on each student who } \\
\text { does the presentation without exception? }\end{array}$ \\
\hline & & $\begin{array}{l}\text { Does the teacher discriminate students in the class } \\
\text { in terms of treatment or assessment? }\end{array}$ \\
\hline
\end{tabular}

Note: DC=Democratic Classroom

The questionnaire was validated by experts including the expert of Indonesian language and education evaluation. The questionnaire was administered to 23 students twice in November 2016, after the first and the second lesson. The follow up interview was conducted in February 2017 for six students. The six students chosen were among the member of the three groups recorded. The interview aims to obtain deep understanding of the students' responses in the questionnaire as well as to investigate their change of perception of the implementation of democratic classroom by their teacher. Descriptive analysis was performed for the data from the questionnaire to obtain information the percentage of students who respond yes or no for the questions related to the implementation of democratic classroom. Positive responses for the positive questions conclude that the teacher implements the democratic classroom. On the other hand, positive responses for negative questions conclude that the teacher does not implement the democratic classroom.

\section{RESULTS AND DISCUSSION}

The students' responses of the questionnaire administered after the first (Q-1) and second meeting (Q-2) as well as the interview responses are presented in Table 2 .

Based on the responses of the first and the second questionnaire as well as the interview results presented in Table 2, it can be concluded that the percentage of the characteristic of the democratic classroom implementation increases for number $1,3,4,5,6,8$, and 12 . The percentage decreases for number 10 and 11 . In addition, there is no change for the percentage of number 2, 7, and 9. Some students' perception shows the decrease of the implementation 
of democratic classroom. This was due to the time constraint which resulted in the teachers were not having enough time to comment on each group presentation, instead teachers gave the audience questions on how they understood the explanation of presenter or whether their answers were different from the one presented. Furthermore, teacher did not always provide students adequate time to express their opinion or conclusion of the lesson because the class is dismissed 30 minutes earlier; students needed to go to the mosque for the noon congregation prayer. In addition, students were also given more time to discuss in the second meeting than the first meeting as the problem given in the second meeting was more difficult. The teacher had tried to allocate equal time for each group to solve the different problems provided in the worksheet to make sure that all problems can be solved and presented within the limited time.

TABLE II. STUDENTS' PERCEPTION OF THE IMPLEMENTATION OF DEMOCRATIC CLASSROOM

\begin{tabular}{|c|c|c|c|c|}
\hline No & $\begin{array}{l}\text { The characteristics of } \\
\text { Democratic Classroom }\end{array}$ & Q-1 & Q-2 & Interview \\
\hline 1 & $\begin{array}{l}\text { Giving the opportunity to } \\
\text { express opinions or } \\
\text { questions during the lesson }\end{array}$ & $82,6 \%$ & $100 \%$ & $100 \%$ \\
\hline 2 & $\begin{array}{l}\text { Giving the freedom to use } \\
\text { tools or other reading } \\
\text { resources during the lesson }\end{array}$ & $60,9 \%$ & $60,9 \%$ & $100 \%$ \\
\hline 3 & $\begin{array}{l}\text { Limiting the time when } \\
\text { you present your group } \\
\text { work }\end{array}$ & $43,5 \%$ & $100 \%$ & $100 \%$ \\
\hline 4 & $\begin{array}{l}\text { Not refuting you during the } \\
\text { presentation }\end{array}$ & $27,3 \%$ & $59,1 \%$ & $100 \%$ \\
\hline 5 & $\begin{array}{l}\text { Giving you freedom to } \\
\text { work on the worksheet } \\
\text { using your own way }\end{array}$ & $69,6 \%$ & $91,3 \%$ & $100 \%$ \\
\hline 6 & $\begin{array}{l}\text { Giving you the opportunity } \\
\text { to criticize your score of } \\
\text { the assessment of the } \\
\text { worksheet }\end{array}$ & $40,9 \%$ & $75 \%$ & $100 \%$ \\
\hline 7 & $\begin{array}{l}\text { Providing you } \\
\text { opportunity to discuss }\end{array}$ & $100 \%$ & $100 \%$ & $100 \%$ \\
\hline 8 & $\begin{array}{l}\text { Suddenly interrupting you } \\
\text { when you express your } \\
\text { opinion }\end{array}$ & $78,3 \%$ & $87 \%$ & $100 \%$ \\
\hline 9 & $\begin{array}{lll}\text { Providing you } & \text { the } \\
\text { opportunity to help } & \text { the } \\
\text { member of your group } & \end{array}$ & $100 \%$ & $100 \%$ & $100 \%$ \\
\hline 10 & $\begin{array}{l}\text { Commenting on each } \\
\text { student presentation }\end{array}$ & $60 \%$ & $38 \%$ & $16,7 \%$ \\
\hline 11 & $\begin{array}{l}\text { Giving you the opportunity } \\
\text { to ask questions, opinions } \\
\text { or the conclusion of the } \\
\text { learning at the end of the } \\
\text { lesson }\end{array}$ & $77,3 \%$ & $86,4 \%$ & $50 \%$ \\
\hline 12 & $\begin{array}{l}\text { Not discriminating } \\
\text { students in the class }\end{array}$ & $95,7 \%$ & $100 \%$ & $100 \%$ \\
\hline
\end{tabular}

NOTE: THE PERCENTAGES SHOW THE NUMBER OF STUDENTS STATING THAT THE TEACHER IMPLEMENT THE CHARACTERISTIC OF DEMOCRATIC CLASSROOM.

Someone' perception depends on the stimulus received in order to give meaning to the environment. Two people may have the opposite interpretation of the same condition (in [15]).
Table 2 also shows that there is a change of perception in the questionnaire and interview. After examining the video recording and the teacher's interview, there are some factors contributing to the change including: 1) the time allocated for administering the questionnaire in the second meeting is shorter, 2) students has been learning with the teacher for a long period to feel more impacts of the implementation of the democratic classroom, 3) Students change their perception in the interview because of the misconception of the teacher mentioned in the questionnaire being the teacher in general and not specifically meant for mathematics teacher. The change of students' perception is in line with [14] who stated that perception is not fixed: it is flexible, reflecting a persons' physiological state.

\section{CONCLUSION}

This study indicates that students' perception of the implementation of the democratic classroom are that teachers allow the opportunities for students to express their opinion or questions, give the freedom to use the tools or other reading resources, do not refute students during their presentation, give students the freedom to work on the worksheet using their own ways, allow students to criticize their score, provide the opportunity for discussion, allow students the opportunity to help the other member of the group who is struggling, and do not discriminate students in the class in term of treatment and assessment. On the other hand, teacher's action which are not categorized into the characteristics of democratic classroom are that the teachers do not comment on all students' presentation but comment only on students who make mistake; and teachers do not always provide students the opportunities to express their opinion or conclusion at the end of the lesson. The implementation of the democratic classroom was not optimum because of the limited time in the classroom. This research implies that a well-planned of lesson time for the activities conducted is necessary for teachers to successfully implement the characteristics of the democratic classroom.

\section{REFERENCES}

[1] F. Jalal, M. Samani, M. C. Chang, R. Stevenson, A. B. Bagatz, S. D. Negara, "Teacher Certification in Indonesia: A Strategy for Teacher Quality Improvement", (Indonesia: Department Pendidikan Nasional Indonesia, 2009

[2] Zulkardi, "Developing a learning environment on realistic mathematics education for Indonesian student teachers" (Doctoral dissertation, University of Twente, Enschede), 2002.

[3] D. Armanto, Teaching Multiplication and Division Realistically in Indonesian Primary Schools: A Prototype of Local Instructional Theory" (Doctoral dissertation, University of Twente, Enschede), 2002.

[4] A. Fauzan, T. Plomp, \& K. Gravemeijer, "The Development of an RME Based Geometry Course for Indonesian Primary Schools". In T. Plomp and N. Niveen (Eds), (Educational design research-Part B: Illustrative cases, Enschade, the Netherlands: SLO, 2013, pp. 159-178.

[5] Soedarto, "Menumbuhkan Pemahaman Demokrasi dan Perilaku Demokrasi melalui Pendidikan di Sekolah", Suara Pendidikan Kalbar, 2005, pp. 18-21.

[6] S. Rowland, "Teaching for democracy in higher education", Teaching in Higher Education, 8(1), 2003, pp. 89-101.

[7] I. Ahmad, H. Said, S. S. S. Mansoq, M. Mokhtar, and Z. Hasan, "How teacher moderates the relationship between democratic classroom environment and student engagement", Review of European Studies, 6(4), 2014, pp. 239-248 
[8] H. E. Korkmaz, and Gümüseli, "Development of the democratic education environment scale", International Journal of Education Sciences, 52(1), 2013, pp. 82-98.

[9] W. Daher, "Student teachers' perceptions of democracy in the mathematics classroom: freedom, equality and dialogue", Pythagoras, 33(2), 2012, pp. 2-11.

[10] K. P. E. Gravemeijer, "Developing Realistic Mathematics Education", Technipress: Culemborg, the Netherlands, 1994.

[11] R. K. Sembiring, "Pendidikan Matematika Realistik Indonesia (PMRI): Perkembangan dan Tantangannya", IndoMS Journal of Mathematics Education, 1(1), 2010, pp. 11-16.

[12] Desmita, "Psikologi Perkembangan Peserta Didik", Bandung: Remaja Rosdakarya, 2012.

[13] J. Pickens, "Attitudes and Perceptions", Organizational Behavior in Health Care. Sudbury, MA: Jones and Bartlett Publishers, 2005.

[14] J. K. Witt, \& D. R. Proffitt, "Perceived slant: A Dissociation between perception and action", Perception, 36(2), 2007, pp. 249-257.

[15] http://managementconsultingcourses.com/Lesson33Perception\& PersonPerception.pdf. [March, 20, 2017] 